\title{
Killer Cell Immunoglobulin-Like Receptor 2DL3
}

National Cancer Institute

\section{Source}

National Cancer Institute. Killer Cell Immunog/obulin-Like Receptor 2DL3. NCI Thesaurus. Code C129041.

Killer cell immunoglobulin-like receptor 2DL3 (341 aa, $~ 38 \mathrm{kDa}$ ) is encoded by the human KIR2DL3 gene. This protein is involved in the modulation of natural killer cell-mediated immunity. 